\title{
DIFFERENT MANIFESTATIONS OF THE RISE OF FAR-RIGHT IN EUROPEAN POLITICS: THE CASES OF GERMANY AND AUSTRIA
}

\section{Selcen $\ddot{O N E R}^{*}$}

\section{Abstract}

The recent rise of the far-right in Europe has been manifested in different fields that create crucial challenges for maintaining peace and stability in Europe. The first, concerns the increasing votes for far-right parties in various local, national and European Parliament elections. Secondly, there has been rise in far-right organizations and far-right violence. Thirdly, there has been normalization of farright discourse in European politics. This article focuses on different manifestations of the rise of the far-right in Germany and Austria and the underlying reasons. Specifically, it compares the Freedom Party of Austria (FPÖ) and Germany's National Democratic Party (NPD) in terms of their party programs, discourse and electoral success.

Keywords: Far-right parties, European politics, Germany, Austria, Freedom Party of Austria (FPÖ), National Democratic Party (NPD)

\section{AVRUPA SIYYASETINDE AŞIRI SAĞIN YÜKSELISSTININ FARKLI GÖSTERGELERİ: ALMANYA VE AVUSTURYA ÖRNEKLERİ}

$\ddot{O} z$

21.yy'da Avrupa'da aşırı să̆ın yükselişi farklı alanlarda kendini göstermektedir, bu süreç, Avrupa'da barışın ve istikrarın korunmasını zorlayan en önemli unsurlardandır. Ilk olarak, yerel seçimlerde, pek çok ulusal seçimde ve Avrupa Parlamentosu seçimlerinde aşırı sağ partilerin yükselen oy oranlarl, ikinci olarak aşırı să̆ örgütlerin sayısının ve aşırı sağ şiddet olaylarının artışı olarak kendini göstermekte, üçüncü olarak da Avrupa siyasetinde aşırl sağ söylem giderek

*Asst. Prof., Bahçeşehir University, Department of International Relations, e-mail: selcen.oner@eas.bahcesehir.edu.tr 
normalleşmektedir. Bu makalede, Almanya ve Avusturya'da aşırı sağın yükselişinin farkl göstergeleri, bunların nedenleri üzerinde durulacak ve bu ülkelerde aşırl sağın yükselişinin ve özellikle Avusturya Özgürlük Partisi (FPÖ) ve Almanya'daki Ulusal Demokratik Parti (NPD), parti programlarl, söylemleri ve seçimlerdeki başarıları açısından karşılaştııllacaktır.

Anahtar kelimeler: Aşırı săg partiler, Avrupa siyaseti, Almanya, Avusturya, Avusturya Özgürlük Partisi, Ulusal Demokratik Parti

\section{Introduction}

The post-Cold War era has seen a rise in the far-right that has influenced European politics. There have also been increases in xenophobia and violence against immigrants, especially after September 11, particularly towards Muslim immigrants, refugees or those who support policies of multiculturalism.

The far-right has moved 'from the margins to the mainstream' of European politics (Mudde, 2013: 2), as manifested in different fields since the turn of the century. The first one is the increasing votes for far-right parties in various local, national elections and European Parliament (EP) elections. Secondly, there has been rise in far-right organizations and far-right violence. Thirdly, there has been normalization and mainstreaming of far-right political discourse, which is the most dangerous one for the future of Europe because it has allowed the far-right to influence the agenda and discourse of mainstream parties, especially those of the Christian Democrats. These manifestations create crucial challenges for maintaining peace in Europe and continuing the European Union (EU) project. As the Oslo killings show, far-right tendencies are not only dangerous for immigrants and minorities; but they also threaten all European societies (Fekete, 2012). It is thus necessary to deal with the new far-right, not only in terms of electoral politics, but also in the other spheres where they have influence (Goodwin et al, 2012: 4).

Various concepts are used for referring to far-right parties, such as 'radical right', 'populist', 'extreme-right', 'right-wing populist' and 'populist radical right' (Mudde, 2007). Mudde (2014: 98-99) uses 'far-right' as an umbrella concept which includes both the extreme-right and populist radical-right. The 'extremeright' rejects democracy altogether, while radical-right accepts democracy but rejects liberal democracy, which includes pluralism and minority rights. Prototypical populist radical-right parties include Front National (FN) in France, Danish People's Party (DF) and Dutch Party for Freedom (PVV). The prototypical extreme-right party is Golden Dawn (CA) in Greece. In this article, the term 'far right' is used, particularly in order to compare one extreme-right party with other extreme-right groups in Germany and the populist radical-right in Austria. 
Far-right parties are represented in the national parliaments of nearly half of 17 West European countries. However, since 1980, more than 200 national governments have been formed in Western Europe but only eight of them included a far-right party, all of which were a junior partner in the coalition. Only three West European countries have ever had a majority government with the participation of a far-right party, although the Netherlands and Denmark had minority governments with their support (Mudde, 2013: 3-4). In the last EP elections in May 2014, far-right parties increased their number to 86 MEPs, constituting $11.45 \%$ of the EP. The FN got $25 \%$ of the vote in France while the UK Independence Party (UKIP) got $27.5 \%$ in the UK (European Movement International, 2014).

The normalization and mainstreaming of far-right discourse of populist rhetoric is coupled with their increasing electoral success. As Hainsworth (2000: 14) argues, far-right parties have influenced the 'agendas, policies and discourse of major political parties and governments', drawing especially far-right and centreright parties closer to each other.

This article will first analyse various manifestations of the far-right's rise in European politics, primarily by focusing on the rise of various types of far-right parties, evaluating their 'others', their discourse about the EU, and their influence in European politics. Secondly, it will account for the rise of far-right organisations and extreme right violence against immigrants, before discussing the mainstreaming of far-right discourse and policies. Finally, it will compare the cases of two EU members, Germany and Austria, who have a shared history, similar political systems, and the same official language. However, the far-right has manifested itself in different ways in these countries. The reasons behind the different manifestations of the rise of the far-right in Germany and Austria will be compared, with particular reference to Freedom Party of Austria (FPÖ), which is one of the strongest far-right parties in Western Europe, and National Democratic Party (NPD) of Germany, which is not represented in Germany's federal parliament. They will be compared in terms of their party programs, discourse and level of electoral success.

\section{Different Manifestations of the Rising Influence of the Far-Right in European Politics}

The primary indicator of the rise of the far-right in European politics is the rise of far-right parties, primarily in local elections, but also in some national and EP elections. Although the new far-right parties emerged in Western Europe in the 1970s, their influence did not increase until the 1980s (Hainsworth, 2008). Mudde (2013: 4-15) argues that, populist radical right parties constitute the most successful new European party family since the end of the Second World War. 
France's FN, founded in 1972 as a collection of far-right groups, made its electoral breakthrough in the mid-1980s, since when it has become the leading example for most contemporary far-right parties in Europe (Goodwin et al, 2012: 25). Many have adopted FN propaganda, slogans or even copied its name and logo (Mudde, 2012: 4). In the late 1990s, Jean Marie Le Pen led attempts to unite the far-right across Europe by creating Euro-Nat, an association of European national parties. Electoral support for far-right parties increased significantly across Western Europe during the 1990s, as rising immigration, unemployment and economic stagnation provided a conducive environment for their discourse (Williams, 2006: 4). Le Pen, for example, won $17 \%$ of the votes in the 2002 French Presidential elections (Gowland et al, 2006: 427).

It is necessary to differentiate extremist and populist versions of far-right parties. Populist far-right parties are characterised by authoritarianism and 'nativism' which, for Mudde (2007: 294-298), refers to the congruence between a state's population and a native group. He categorises France's FN and Austria's FPÖ as examples of such populist radical right parties. They are usually against pluralist democracy, while promoting 'traditional' moral and religious values. Although they usually deny any association with racism, they argue that social welfare benefits should be restricted to people of the country's dominant ethnic group (Gowland et al, 2006: 428-429). On the other hand, NPD in Germany and Golden Dawn in Greece are examples of extreme-right parties with exclusivist rhetoric and policies towards immigrants, refugees or minorities. Various countries have banned or withheld registration of far-right parties in accordance with antidiscrimination and anti-extremist legislation. These include the National Democratic Party in Austria, the National Socialist Block in the Czech Republic, and, Centre Party ' 86 in the Netherlands. In the UK, the Equality and Human Rights Commission opened a legal case against British National Party (BNP) which forced the party to amend its rules so that it officially accepted non-whites as members (Hamilton, 2009).

In contrast to the fascist parties of the interwar years, today's far-right parties usually accept representative democracy while criticising liberal values (Brandt, 1996: 26). Due to increasing evidence of mainstream party representatives' involvement in corruption, public trust in them has declined. In this atmosphere, far-right parties have become more influential in European politics, as they have become more attractive to electorates dissatisfied with mainstream political parties (Hainsworth, 2000).

Some far-right parties have tried to distance themselves from the inter-war fascist movements. Currently, many far-right parties, including those in Belgium, Austria, France and Italy, do not use autocratic political arguments. Rather than abolishing democracy, they seek to transform it into 'ethnocracy'. Nearly all far- 
right parties share an exclusivist understanding of the 'nation' as homogeneous (Minkenberg, 2011: 42), using similar slogans, such as the Republikaner's 'Germany for the Germans, foreigners out!' (Schori Liang, 2007: 10). Such slogans reflect their desire to link national affiliation rights to benefit from the welfare state to ethnic criteria (Minkenberg, 2011: 42).

For the new far-right, especially after September 11, immigrants, particularly Muslim immigrants, became Western civilisation's most serious threat, and were usually portrayed as the most difficult group to assimilate (Guibernau, 2010: 4-11). In recent years, especially in Western Europe, the primary focus of far-right parties has been radical Islam, followed by immigration, which they link to security, particularly to crime and terrorism. The third issue is the economy, with immigration seen as a threat to the wealth and welfare of the nation, and the accusation that corrupt elites use immigration for financial and political gain (Mudde, 2012, pp. 31-32).

The electoral success of far-right parties is usually gained locally, as in Germany. Such local and regional successes are particularly important for achieving long-term success in national elections (Langenbacher \& Schellenberg, 2011: 21). The success of far-right parties does not only depend on the degree of extremism in their discourse; but it is also related to other factors, such as organisation, leadership and experience of participation in government (Wilson \& Hainsworth, 2012: 11). According to Mudde (2007: 275-276), successful far-right parties, such as FN, are usually characterised by a moderate ideology, a strong organization structure and a charismatic leader.

National election results since the global recession started to influence Europe in 2008 indicate that some far-right parties have increased their votes, such as Jobbik in Hungary in 2010 and National Alliance in Latvia in 2011. However, the EP elections in June 2009 gave no clear indication of increasing far-right electoral success. On the one hand, Jobbik got $14.8 \%$ in its first EP election, and the British National Party and Dutch PVV both increased their votes, by 1.4 and 17 per cent respectively. On the other hand, other far-right parties lost votes, such as VB ($3.4 \%)$ and FN (-3.5\%). Moreover, in most European countries, far-right parties either did not take part in the EP election in 2009 or failed to gain sufficient votes to win EP seats, as in Germany, the Czech Republic, Finland and Spain (Mudde, 2012: 29).

The recent economic crisis has provided a suitable atmosphere for the development of the far-right, with the neo-Nazi Golden Dawn party winning 7\% of the vote in the Greek general election in May 2012 (Fekete, 2012: 30). Rising unemployment has also encouraged the rise of the far-right, although the rise can also be observed in more prosperous European countries, such as Denmark and the 
Netherlands. The far-right's voters are not only from the working class; they are supported also by some well-educated, middle-class voters (Guibernau, 2010). Goodwin (2011) argues that, rather than economic concerns, their voters' main motivation is cultural anxiety about the influence of immigration on national identity.

At the last EP elections in 2014, there was a crucial rise in far-right parties. The extreme-right Golden Dawn of Greece got $9.38 \%$, FPÖ got $12.71 \%$ in the 2009 EP elections and $19.70 \%$ in the last EP elections. In France, FN, having got $6.3 \%$ in the previous EP elections, became the first party in France in the last EP elections with $24.95 \%$ votes. ${ }^{1}$ In addition, as mentioned, the former leader of NPD, Voigt, entered the EP in the last EP elections in 2014.

The far-right parties offer exclusionist policies through constructing the dominant ethnic and religious group as 'us' and other groups as 'them'. Increasing xenophobia, in terms of fear, prejudice and even aggression towards immigrants, has increased the electoral success of far-right parties in Europe.

Far-right parties usually claim that their native culture is threatened by immigrants (Williams, 2010: 113), while also being pessimistic about the possibility of integrating them (Fligstein et al, 2012: 116). According to Mudde (2007: 66), for far-right parties, the first type of 'other' refers to anything outside the state and nation, such as the EU. The second type of 'other', lies outside the state but within the nation. This group includes politicians and intellectuals who have emigrated and are accused of corruption. The third type of 'other' includes those within the state and within the nation, such as the economic and political elites, who are characterized as corrupt elements. The last type of 'other' refers to immigrants, who are within the state but outside the nation.

Some scholars argue that Muslims, especially immigrant Muslims, have replaced Jews as the new transnational 'other' in Europe ${ }^{2}$ (Zuquete, 2008: 329; Langenbacher \& Schellenberg, 2011: 18), especially after September 11. In a speech before France's 2007 elections, former President of FN, Le Pen, stated that Islam in the $21^{\text {st }}$ century is what communism was in the $20^{\text {th }}$ century (cited in Poggioli, 2006). FN's current leader, Marine Le Pen, argues that 'Europe will no longer be Europe. It will turn into an Islamic Republic. We are at a turning point, and if we do not protect our civilization it will disappear' (cited in Amnesty International, 2012: 17), while Geert Wilders, leader of Party for Freedom (PVV) in the Netherlands, claims that 'Islam is the biggest threat, threatening our country and the entire free Western world' (cited in Amnesty International, 2012: 17).

\footnotetext{
${ }^{1}$ For further detail, see http://www.results-elections2014.eu/en/election-results-2014.html

${ }^{2}$ For further detail, see D. Boyer (2005) Welcome to the new Europe, American Ethnologist, 32 (4).
} 
In the last two decades, political parties promoting an anti-Islamic discourse have achieved crucial electoral successes that have even enabled them to enter national parliaments and join governing coalitions in several states, such as Austria. These parties have instrumentalized public sentiments of anxiety through their warnings of the 'Islamization of Europe' (Amnesty International, 2012: 1516).

On the other hand, in Eastern Europe, the 'others' of the far-right parties include minorities, such as Roma or Turks in Bulgaria (Langenbacher \& Schellenberg, 2011: 18). Anti-Roma discourse is especially common among Eastern Europe's far-right parties, such as National Union Attack (Bulgaria) and Jobbik (Hungary), although it has also been intensifying in France and Italy (Fekete, 2012: 6-11).

Europe's far-right parties favour a cultural understanding of national and European identity, usually defining themselves through their national identity. Zuquete (2008: 332) argues that the increasing emphasis on a European identity in far-right parties is usually associated with the increasing construction of 'Islam' as the 'other' of Europe. Because of the nationalistic elements in their ideology, farright parties are against supra-nationalism, considering it as an enemy of the nation-state. Especially after the Maastricht Treaty, the EU became perceived by far-right parties as signalling a significant loss of national sovereignty. They usually see Brussels as corrupt, and controlled by the political and technocratic elites. The majority of far-right parties therefore reject the idea of a federal Europe, claiming that it will lead to a multicultural Europe in which national identities will be eroded (Schori Liang, 2007: 11-13). Far-right parties have successfully engaged young people and workers in politics (Goodwin et al, 2012: 19) with their main supporters being those who are strongly attached to their national identities, and who may be the losers or at least the ones not benefiting from the EU project (Fligstein et al, 2012: 114).

Far-right parties are mostly Eurosceptic or, in many cases, anti-EU (Mudde, 2007: 162). Some are 'hard Eurosceptic', meaning that they are totally against the European integration project, even favouring their country's withdrawal from the EU. Those that are 'soft Eurosceptic' criticize certain aspects of the EU (Vasilopoulou, 2011: 224-225), being more in favour of intergovernmental cooperation in the EU.

Far-right parties are mostly against Turkey's EU membership. As Delanty (2008: 681) argues, Turkey's bid for EU membership is controversial because of fears that it will lead to a new influx of immigrants and result in the Islamification of Europe (although this disregards the secular character of Turkey's constitution). A number of far-right leaders have made statements along these lines. Le Pen 
claimed that Turkey's possible membership signalled the 'true Islamic invasion of Europe' (cited in Zuquete, 2008: 331), while Christoph Blocher, leader of the Swiss People's Party, stated that 'we had the Turks at the gates of Vienna once, we do not need that again' (cited in Schulz, 2011: 31). In short, rejection of Turkey's EU membership bid is a common discourse of far-right parties, especially in Western Europe. This also usually influences the discourse of centre-right parties.

In 2005, representatives from seven far-right parties $^{3}$ prepared the Vienna Declaration of Patriotic and National Movements and Parties in Europe, calling for a rejection of EU enlargement to non-European regions, an immediate stop to immigration, restriction of social benefits to immigrants and rejection of the Constitutional Treaty (Fligstein et al, 2012: 115). Having agreed to meet annually and establish a 'Contact Forum for European Patriotic and National Parties and Movements', they established an office in Vienna (cited in Schori Liang, 2007: 1314).

There has thus been increasing interaction and cooperation between far-right movements and political parties in Europe, although they have found it harder than other political groups to establish a transnational federation. One of the main unifying factors is 'anti-Islamism'. For example, Pro Cologne participated in a European network called 'Cities against Islamisation' that includes FPÖ and Vlaams Belang (VB) from Belgium. Important figures from far-right parties across Europe came to Cologne for anti-Islam conferences in 2008 and 2009 (Schellenberg, 2011: 78).

At the EP level, far-right groups have formed two political parties. The first is the Identity, Tradition and Sovereignty Group (ITS), which includes members of FN, VB, Bulgarian Ataka and Greater Romania Party (PRM); the other party is the conservative Union for Europe of the Nations (UEN), which includes Liga Nord and Dansk Folkeparti (DFP) (Fligstein et al, 2012: 115). ITS was established after the accession of Romania and Bulgaria to the EU in 2007. To monitor the activities of this party at the EP, the socialist parties established the 'Extreme Right Watch Group'. Ironically, the far-right EP group collapsed within its first year because its Deputy Chairperson, Alexandra Mussolini, refused to accept PRM's complaint that Romanians in Italy were being treated as if they were all Roma (Schulz, 2011: 34). In 2009, Alliance of European National Movements was formed by Jobbik, FN, Belgium's National Front, Sweden's National Democrats and Italy's Tricolour

\footnotetext{
${ }^{3}$ The representatives who participated in the preparation of Vienna Declaration of 2005 were from FPÖ, VB, Ataka, FN, Italian Azione Sociale and Movimiento Sociale-Fiamma Tricolore (MS-FT), Romanian PRM and Spanish Alternativa Espanola.
} 
Flame (Goodwin et al, 2012: 18). ${ }^{4}$ In the last EP elections, most members of the European Parliament (MEPs) from far-right parties became part of the 'noninscrits', who are unattached to any political group at the EP.

One important factor facilitating the increase in cooperation among far-right parties is the Internet as far-right parties usually have well-designed websites and use social media effectively (Goodwin et al., 2012: 3). Thus, there has been increasing transnational cooperation among far-right parties in Europe. However, because of variations among their approaches and their nationalist concerns, farright transnational cooperation has not usually been sustainable.

The second manifestation of the rise of Europe's far-right is the growth in farright organizations and far-right violence. The 1990s saw significant incidents of extreme-right violence in Germany, Scandinavia and certain Central and Eastern European countries. However, the correlation between the strength of far-right parties and extreme-right violence is unclear because there is a lack of reliable cross-national data on extreme-right violence, as most countries lack a central agency to collect such information (Mudde, 2012: 23).

Violent right-wing extremism involves a wide range of people, including members of far-right parties but also individuals who engage in violent activity. Similarly, while far-right social movements, trying to mobilise public support for their cause, do not usually involve themselves in violence, they may still become a home for violent individuals. Finally, there are so-called 'lone wolves' like the extreme-right Norwegian mass-murderer, Anders Breivik, without any formal links to established groups (Goodwin et al, 2012: 6). Breivik's extreme-right terrorist attack in 2011 put the spotlight on extreme-right terrorism, leading to several critiques that claimed the attack could have been prevented if European states had given more attention to extreme-right terrorists rather than just focusing on Islamist terrorists (Mudde, 2012: 23), as has been the case in the past decade, as Western states mainly concentrated on fighting al-Qaeda or 'AQ-inspired terrorism' (Goodwin et al, 2012: 38).

The third manifestation of the rise of far-right in European politics is that farright parties have influenced the styles of leadership and discourse of mainstream parties (Goodwin et al, 2012: 19), bringing the two groups closer to each other. The main influences of the far-right parties on mainstream parties are their antiimmigration discourse and being against Turkey's EU membership (Mudde, 1999).

Thus, the level of support for far-right parties in local, national and European elections, their coalition-building with centre-right parties, and their influence on

\footnotetext{
${ }^{4}$ At the end of 2011, Marine Le Pen resigned from this group and joined the more moderate European Alliance for Freedom.
} 
the discourse and policies of mainstream parties all show their increasing influence in European politics. While no far-right party has achieved a ruling majority in any national parliamentary election in Europe yet, as mentioned, they have been part of coalition governments with centre-right parties (Fligstein et al, 2012: 115).

One of the effects of the rise of far-right parties in European politics is that they have challenged Social Democratic Parties by attracting working-class voters, who have traditionally supported the centre-left, which may also facilitate the formation of centre-right governments (Bale et al, 2010: 410). This also forces mainstream parties to search for a balance between ignoring and cooperating with far-right parties (Goodwin et al, 2012: 28).

Right-wing parties, such as the British Conservative Party, the Dutch People's Party for Freedom and Democracy and the French Union for a Popular Movement, have adopted far-right positions more often than left-wing parties. However, there are also examples of social democratic and even communist parties that have adopted anti-immigration positions, such as the Dutch Labour Party and French Communist Party. They have even influenced changes in immigration laws in France, Austria, Denmark and the Netherlands (Norris, 2005).

Consequently, in recent years, the lines between violent and non-violent rhetoric, extreme and non-extreme have become blurred, while negative rhetoric towards immigrants and minorities has become normalised. These trends may pose a threat to pluralistic democracies in Europe (Goodwin et al, 2012: 30). Mainstreaming of far-right discourse and policies is one of the biggest challenges to peace in Europe in the $21^{\text {st }}$ century. It may provide a more suitable platform for the rise of far-right with various manifestations that were mentioned in European politics.

\section{The Rise of the Far-Right in Western Europe: The Cases of Germany and Austria}

The different manifestations of the rise of the far-right in Western European politics can be analysed by comparing the cases of Germany and Austria, who have a shared history, similar political systems, the same official language, and who are both members of the EU. Austria and Germany both have a high number of Turkish immigrants and public opinion in these countries is mostly against Turkey's membership to the EU. Austria and Germany share similar immigration histories, as both implemented 'guest-worker policies' from the 1960s until 1974, when 'recruitment stops' were implemented. Since the 1990s, the issue of immigration, integration and citizenship has become more important in German and Austrian politics. They have similar nationality laws regarding the acquisition of citizenship, both relying on the 'jus sanguinis' principle, referring to ethnic descent, although Austria made some amendments to its nationality law in 1999 
and Germany in 2000. In Germany, the principle was softened by introducing a limited 'jus soli' principle (Ludvig, 2004: 499-505), meaning that citizenship can now be acquired based on birthplace, allowing automatic German citizenship for a child born in Germany to foreign parents if at least one of the parents has lived legally in Germany for at least eight years and holds a permanent residence permit.

While Islam is still not recognised as an official religion in Germany (Mudde, 2007: 84-86), it gained official recognition in Austria in the $19^{\text {th }}$ century and was finally given equal status with other religions in 1912. This is a historical legacy of the Austro-Hungarian Empire, which included Bosnia and Herzegovina (Schmied \& Wieshaider, 2004: 202).

The rise of the far-right in Austria has been reflected in the federal parliament election results of two far-right parties, FPÖ and BZÖ, which can be defined as 'populist far-right parties'. In Germany, the rise of the far-right has not yet been reflected in federal elections. However, it can be seen in local elections in some regions of Germany, while their influence can be also seen in the high number of far-right organisations and extreme-right violence against immigrants, refugees or against those who are perceived as supporters of multicultural policies. Research shows that extreme-right violence is not directly related to the presence and strength of far-right parties (Mudde, 2012: 31). In Germany, the far-right parties have a fragmented and weak structure, although the far-right movements are strong (Minkenberg, 2011: 47). In 2010, an annual report found that, while membership of far-right parties in Germany had declined, affiliations to non-electoral, neo-Nazi groups were on the rise (cited in Goodwin et al, 2012: 40).

In the following sections, different manifestations of the rise of the far-right in Germany and Austria are analysed. Particularly, the reasons behind the different manifestations of the rise of far-right in Germany and Austria, and, the party programmes and the discourse of FPÖ of Austria and NPD of Germany are scrutinized in detail.

\section{The Far-Right in Germany: the National Democratic Party (NPD), Far- Right Movements and Extreme-Right Violence}

After the Second World War, there was only a restricted political space for farright parties in Germany because of sensitivities due to the country's Nazi past. Since then, there has also been careful suppression of far-right parties through cross-party consensus while maintaining democratic competition (Howard, 2001: 18). According to Nedelcu and Miller (2011: 62), the far-right in Germany has become radicalized by a number of factors: The Christian Democratic Party (CDU) has a well-established anti-immigration position and there is restricted political

\footnotetext{
${ }^{5}$ Acquiring German citizenship, retrieved on March 14, 2012, from http://sachsen.de/en/1444.htm
} 
space for the far-right. Political, media and public discourse about immigration and Islam in Europe, particularly in Germany, have also influenced the level of support for the far-right (Williams, 2010: 112).

Compared to other western European countries, far-right parties in Germany have had relatively very little electoral success in federal elections. There are several far-right parties in Germany, such as Republicans (REP) and German People's Union (DVU). However, this article will focus on National Democratic Party of Germany (NPD) which is the most influential. None have entered the Bundestag yet, although REP won 7.1\% at the EP elections in 1989. At local and regional levels, however, far-right parties have significant strength. NPD, DVU, REP, Stop Foreigners action group and Pro-Cologne group all have seats in several local assemblies and municipal councils (Schellenberg, 2011: 64).

NPD was established in 1964, with many members being former Nazis. The party's initial programme included pro-Nazi, anti-Communist and Catholic elements. Udo Voigt was the chairman of the party between 1996 and 2011 before Holger Apfel took over in 2011 till he was replaced by Udo Pastörs in December 2013. The new programme of the party was prepared in 1996. It is nationalist, populist, favours a form of national socialism, and includes anti-capitalist and nationalist revolutionary elements. The party is hostile to the ruling system, and propagates a biological understanding of race that favours the expulsion of immigrants (Schellenberg, 2011: 58-59). Despite its extreme policies, in 2002, the Supreme Court dismissed an attempt by the state to ban NPD. In January 2011, DVU merged with NPD. However, Munich Regional Court declared the merger null and void. Discussions and attempts to ban NPD continue in Germany. A number of other far-right parties in Europe have kept their distance from NPD as it is usually perceived as representing an extreme form of the far-right that includes La Falange from Spain and Forza Nuova from Italy.

NPD claims that German culture has been affected by foreign influences since the Second World War, arguing that 'German virtues have been undermined by American cultural imperialism and non-European immigrants' (Williams, 2010: 114). The party programme lists various threats to the German 'nation':

In the $21^{\text {st }}$ century whether the German nation will survive or abolish will be clarified. The sources of threats for its existence are the decline in birth rates, quickly spreading alienation, the enforcements of international organizations, and the dreadful effects of globalization (NPD Party Programme, 2010: 5).

For NPD, 'Germans have to choose between to be a social state or to be an immigration country' (NPD Party Programme, 2010: 6). The party programme (2010: 11) requires that foreigners should be excluded from the German social 
security system and placed under a new social security law. According to the programme (2010: 12):

Because of crowds of naturalizations, German citizenship rights are abused and even the right of existence of German nation is nearly to be questioned. In order to overcome this decay, the previous citizenship system of 'jus sanguinis' has to come into force again. For NPD, 'multicultural' society is unsuccessful. In many cities parallel societies and ghettos are emerging, thus, German people in these regions have become minorities in their own countries.

The party programme (2010: 5) emphasizes that:

Germany should stay the country of Germans and when it was not like this it has to be returned to this character again. Permanent residence permits should not be given to the foreigners in Germany. On the contrary, they have to be pushed to return back to their countries... Germany's alienation on an ethnic basis through immigration has to be prevented decisively like cultural alienation which is caused by Americanization and Islamization.

NPD is even against the integration of immigrants. 'The foreigners, who come from different countries for several job opportunities have to protect their identities. This will facilitate their return to their countries' (NPD Party Programme, 2010: 13). It perceives international organizations like the EU as a threat to the sovereignty of the state and autonomy of the people so it takes a 'hard Eurosceptic' approach, arguing that 'national sovereignty means that German state sovereignty and independence have to be reconstructed and for this it is necessary to leave EU and NATO' (NPD Party Programme, 2010: 5). The party has an exclusivist understanding of European identity. For NPD, states like Turkey, which supposedly have totally different social and cultural structure, cannot be part of Europe, and claims that Turkey's EU membership would trigger increased crime (NPD Party Programme for Europe, 2003: 15-20) because of the rise of Turkish immigrants after Turkey's accession to the EU.

Regarding violence, offences motivated by the extreme-right have increased significantly in Germany in recent decades, leading it to have the highest level of extreme-right violence among western European countries. In 2002, there were 10,902 extreme right offences and 19,894 in 2008 (Schellenberg, 2011: 71-72). Die Zeit recorded that 137 victims have been killed by racist violence in 20 years since Germany was reunited (cited in Schellenberg, 2011: 72). Such violence is more common in the east than the west of the country (Brandt, 1996: 36).

After the attacks on hostels for asylum seekers in Hoyerswerda and Rostock, and the racist murders in Solingen and Mölnn, some extreme-right organizations were banned, but in response they simply stopped applying for official status, 
creating instead more flexible associations of 10 to 30 people in a loose network. Because of their loose autonomous structure, they can largely escape state repression, although a few of these groups were also banned (Schellenberg, 2011: 68-69).

Germany's Office for the Defence of the Constitution regards anti-capitalist groups like the 'Autonomous Nationalists' and the 'Free Forces of National Resistance' as a greater threat than NPD. However, there is also an interplay between old and new forms of far-right activity in that NPD has become dependent on groups like the 'Autonomous Nationalists' to mobilise its supporters on the streets (Fekete, 2012: 23).

There have been a growing number of far-right internet sites in Germany, which the state has not usually been able to suppress because these groups may cooperate with foreign servers, which means their sites are not subject to the legal requirements of the German constitution (Schellenberg, 2011: 77-78).

As a result, the German state has engaged in suppression of far-right parties through cross-party consensus while maintaining democratic competition (Howard, 2001: 18). However, extreme-right attacks are still widespread in Germany. AntiSemitism is still crucial for the far-right in Germany. Because of the internal problems and state restrictions, far-right parties will find it hard to gain electoral success at the national level in the foreseeable future (Schellenberg, 2011: 79). On the other hand, the former leader of NPD, Udo Voigt became the first MEP from NPD in the last EP elections in 2014. The German Constitutional Court has successfully limited the spread of the organized far-right movement (Howard, 2001: 29). However, this has not been enough to prevent far-right violence in Germany, which is much higher than in other Western European countries.

\section{The Far-Right in Austria: The Role of Populist Far-Right Right Parties and the Case of the Freedom Party of Austria (FPÖ)}

After the Second World War, mainstream parties in both Germany and Austria reached an elite consensus not to cooperate with, or even tolerate the few small farright parties and movements that existed in the early post-war period. This exclusion meant that they remained marginal in political party systems. However, this process took a different form in each country, which led to different consequences. In Germany, the elite consensus was enforced by the Constitutional Court, through its power to outlaw any political parties or organizations with farright views. In Austria, the elite consensus was not implemented by the Constitutional Court; rather, the two mainstream parties (Social Democrats and People's Party) cooperated to exclude potential competitors, in what became known as the 'Proporz system'. As long as these parties continued to cooperate, this denied opportunities for far-right parties to threaten the democratic system. 
FPÖ, which was established in 1956 as a continuation of the post-Nazi 'Association of Independents', was thereby excluded by the mainstream parties for a long period. However, this changed in the late 1970s, when Social Democrat Chancellor Kreisky tried to weaken the People's Party by helping FPÖ to increase its influence. Between 1983 and 1986, the Social Democrats under Vranitzky included FPÖ as a junior partner in the coalition government. Then, between 1986 and 1999, the Social Democrats and the People's Party formed an ineffective 'grand coalition', which allowed FPÖ to enhance its credibility as the major opposition party (Howard, 2001: 22-24).

In the November 1999 elections, FPÖ won $27 \%$ of the votes, becoming a partner in the coalition government with the Christian Democrats. In protest at the inclusion of Haider's party in the coalition government, the other 14 member states of the EU announced that they would suspend bilateral links with Austria, reduce contact with Austrian ambassadors and oppose Austrian candidates for international positions. This reaction had symbolic importance in demonstrating that far-right parties were against the values of the EU. However, in September 2000, an EU report convinced other member states to lift diplomatic sanctions against Austria as the response had served its purpose (Howard, 2001: 25-31) of sending a signal to the Austrians and other Europeans about the EU's official position towards the far-right.

In 2002, disputes within FPÖ over elections caused the resignation of several members, which led to the collapse of the coalition government and Haider's resignation as FPÖ chairman. In the 2002 elections, FPÖ lost more than half of its votes, although it still became a coalition partner in the subsequent government. FPÖ then split, with the formation of the Alliance for the Future of Austria (BZÖ), led by Haider.

FPÖ perceives immigration and Islamism as challenges to Austrian and European identity. For example, in a 2007 press release, Strache, leader of FPÖ, claimed that, 'challenged by globalisation and modern migration, our identity is increasingly threatened in the cultural, religious, as well as the political domain' (cited in Strasser, 2008: 183). He worried about the demise of the Occident, claiming that 'we shall end up in a mono-cultural future of Islamism, if we do not fight back' (cited in Strasser, 2008: 183).

According to an Austrian federal parliamentarian from FPÖ interviewed by the author, FPÖ is a nationalist conservative party rather than a far-right party:

There are three cornerstones that differentiate us from the rest of the political spectrum in Austria and from most other parties in Europe. We want to preserve the particular identity of the nations of the states and of Europe as a whole. [...] Second is independence: [...] limiting the amount of power we 
give to the EU. [...] we say too much power has already been transferred to the EU. [...] We should re-nationalize parts of the politics, especially where EU has had an obvious failure. For example, the monetary policy is a disastrous failure. [...] Third [...] we do not think it is correct that European Court has made the supreme legal decisions for member states. (Interviewee, 2012).

The Interviewee noted various differences with the centre-right party in Austria, stating that there are some points on which they agree but there are also a lot of subjects on which they do not agree at all. In his view the main point of difference is that the People's Party is in favour of federal Europe, whereas FPÖ is in favour of an EU with an intergovernmental structure (Interviewee, 2012). According to FPÖ's party programme (2011), 'the basic constitutional principles of sovereign member states must have absolute priority over Community law'.

On the other hand, although the FPÖ's party programme (2011) emphasizes that Austria is not a country of immigration, the programme does allow that 'legal and legitimate immigrants, who are already integrated, who can speak German language, who fully acknowledge our values and laws and have set down cultural roots should be given the right to stay and obtain citizenship'. On the other hand, the interviewee from FPÖ (2012) noted a correlation between the level of immigration and unemployment, claiming that 'we must jointly limit immigration. [...] We cannot fight against unemployment, particularly youth unemployment, without taking into account the problems of immigration':

We should limit immigration to the internal needs of the abilities of society and labour market to absorb immigration. [...] It should be 'us' deciding whom we allow to immigrate and in what number, and it should not be done by misusing the instrument of asylum and illegal immigration. [...] It should be done in the neighbouring country. [...] We should have a very tough line on asylum seekers, especially when they pass through twenty other states with no crisis and no war, just to apply for asylum in Austria. (Interviewee, 2012).

In the 2004 EP elections, concern over Turkey's EU membership bid lay at the core of FPÖ's campaign, which also influenced the positions of other political parties in Austria in that just before the elections, the leading candidates of all parties expressed their opposition to Turkey's EU membership (Bunzl, 2005: 506). Regarding EU enlargement, the interviewee from FPÖ (2012) argued:

For us the limit is the geographical border of Europe. That is why we are against Turkey's membership. We think the maximum we can do is [...] the Western Balkans. [...]Within the next 5 to 15 years I think they will all be members of the EU. [It] may take time in the case of Albania, Kosovo. [...] We must be open in some way towards Ukraine, Moldova, if there is a change, towards Belarus. Why do we exclude Turkey? [...] The more 
different cultures you integrate into the EU, the more likely that everything will explode. [...] So different models of society, Greek, German, and Portuguese - they are already over-integrated and tension is so high and it does not work. The more different social models we integrate in that, the more difficult it will become.

In short, he does not perceive Turkey as European, either in geographical or cultural terms; thus, he finds Turkey's integration to the EU the most difficult of all the candidates and even other neighbouring countries of the EU.

The former leader of FPÖ, Haider, also referred to history when talking about Turkey's EU membership: 'For what reasons did our ancestors defend our country against the Turks if we are now letting them in again?' (cited in Gingrich, 1998: 104). When Haider was the leader of FPÖ, the party's main slogan was 'Turkey into the EU? Not with me!' FPÖ pamphlets claimed:

Just because 3\% of Turkey happens to be in Europe geographically does not mean that Turkey is a European state [...] Turkey's state institute for statistics forecasts a population of 95 million for the year 2050. The country with the highest population in the EU would then be Islamic' (cited in Bunzl, 2005: 505).

During its campaign for Vienna City Council elections in 2005, FPÖ used various discourse against immigration, Turkey, Turks and Muslims. BZÖ was also against negotiations with Turkey (Strasser, 2008: 180-181). In the campaigns of far-right parties in Austria, Turkey and Turkish immigrants, who are the biggest Muslim community in Austria, are presented as an important threat. FPÖ's leader Strache, was portrayed as the new Prince Eugene, who had saved Vienna from the Turkish siege of 1683. In 2004, even the Social Democrats, as the opposition party, rejected Turkey's membership bid. This attitude, a sign of the mainstreaming of far-right discourse in Austria, can be related to their need to regain the support of working class and retired voters, who had become more attracted by far-right propaganda that included elements of xenophobia and Islamophobia. During that period, both the opposition and its base pushed the Austrian government, which included the Christian Democrats (ÖVP) and FPÖ, to prevent the start of accession negotiations between Turkey and the EU. In the end, however, the Austrian government relented after the decision was taken to start negotiations with Croatia at the same time as Turkey in 2005. In response to criticism of this stance, the Chancellor of Austria stated that even if Turkey successfully completed the negotiations, a referendum would be held over accepting Turkey's EU membership. In the 2006 election campaigns, FPÖ used slogans such as 'No to a Turkish EU', claiming that Islam and Turkishness are incompatible with Austria and Europe (Günay, 2009: 105-109). 
On 23-24 October 2010 FPÖ was organized a meeting in Vienna to increase cooperation between right-wing parties, with Christian Democrat parties being particularly influential. The participants decided to start a referendum campaign over Turkey's EU membership bid, with Strache arguing that it would be wrong to accept 'non-European' countries into the EU because this would represent a 'Europe-Asia-Africa Union'. ${ }^{6}$

In contrast to NPD, FPÖ's party programme (2011) emphasizes that they are against extremism:

We are prepared to put up a resolute defence of these European values and our basic liberal-democratic order against fanaticism and extremism and to take action to maintain and develop our dominant culture and our way of life in peace and in freedom.

As a result, although NPD and FPÖ share some discourse about antiimmigration and anti-Islamization of Europe and both are against Turkey's EU membership, there are also important differences between them. Firstly, NPD is an extreme-right party and cannot gain representation in the federal parliament, whereas FPÖ is a populist radical-right party, represented at the federal parliament, has closer relations with mainstream parties and has even been part of the federal government. Secondly, NPD is anti-EU, whereas FPÖ is soft Eurosceptic and more in favour of an intergovernmental EU; NPD has a more restrictive immigration policy, even being against giving citizenship for integrated immigrants, unlike FPÖ which is not against integrated immigrants.

\section{Conclusion}

There has been resurgence of far-right politics that has led to a mainstreaming of anti-immigrant and anti-Muslim discourse (Goodwin et al, 2012: 3) and far-right parties have become more successful electorally. They have learned from their mistakes and gained experience at regional and local level. Far-right parties claim that centre-right or centre-left governments are all the same and emphasize that an alternative is needed (Wilson \& Hainsworth, 2012: 15). New far-right parties are implementing a new style of politics that relies increasingly on young, educated and charismatic leaders to overcome their old reputations. In addition, they use new technologies, expert campaigners and try to mobilise across national borders (Goodwin et al, 2012: 4).

The main themes of far-right rhetoric are anti-immigration, usually 'hard Euroscepticism', anti-Islamism, and emphasising national identity and security. Immigration is perceived as a challenge to culture, national identity and European

${ }^{6}$ For further detail, see www.ikv.org.tr/.../avrupada_asiri_sag_partiler_turkiyenin_ab_uyelig, Retrieved at: March 8, 2012. 
identity, the security of the country, and a drain on the welfare system. There is no clear relationship between the number of immigrants and extremist violence; neither is there a correlation between the electoral strength of far-right parties and the level of extremist violence in each country (Mudde, 2012: 31).

The Eurozone crisis has provided a suitable platform for the rise of far-right tendencies, providing a political opportunity structure which has been used by farright parties. It therefore seems that they will not disappear in the near future because the circumstances out of which they emerged and developed will not change soon (Wilson \& Hainsworth, 2012: 3-5).

Although there are some similarities, there are crucial differences between the far-right in Germany and Austria. Both of them are against Turkey's accession to the EU. One of the main differences is that far-right parties are not so strong in Germany and remain unrepresented in the federal parliament, but the far-right has manifested itself with several violent attacks by extreme-right groups while in Austria the populist far-right party FPÖ is represented in the federal parliament and the violent attacks by extreme-right groups are rare. In both countries, the far-right discourse has influenced mainstream parties, especially the Christian Democrats. While NPD cannot enter the German federal parliament and it is mostly considered as an extreme-right party, FPÖ even joined the coalition government. While NPD is even against integrated immigrants, FPÖ accepts the integrated immigrants. While NPD is totally against the EU, FPÖ is in favour of an intergovernmental EU.

On the one hand, the far-right's rise in European politics should not be exaggerated. Media attention on such parties has sometimes been higher than their actual level of success (Ellinas, 2010). On the other hand, its significance should not be underestimated either (Goodwin et al, 2012: 3). That is, a balanced approach is needed towards the rise of far-right in European politics.

The rise of the far-right across Europe in different forms is one of the main challenges to peace in Europe and represents a challenge to the EU project in the $21^{\text {st }}$ century. A common discourse and consistent policies against far-right groups are needed, especially against extreme-right violence in Europe. In particular, the EU has to develop consistent policies and develop new measures to fight against xenophobia and Islamophobia. At national level, mainstream parties need to be more effective and successful, especially in terms of social and economic policies, particularly concerning the challenge of rising unemployment rates. In short, a coordinated approach is essential towards the rise of far-right among the EU and its member states, and within member states, while public authorities and NGOs need to work together to fight against the rise of Europe's far-right. 


\section{References:}

Amnesty International Report, Choice and Prejudice: Discrimination against Muslims in Europe, (April 2012), London, pp. 1-123.

Brandt, P., (1996), "Will Fascism Return? Germany and Europe in the Mid-90s", Debatte: Journal of Contemporary Central and Eastern Europe Vol.4, No.1, pp. 21-40.

Bunzl, M., (2005), "Between anti-Semitism and Islamophobia: Some Thoughts on the New Europe", American Ethnologist, Vol. 32, No.4, pp.499-508.

Delanty, G., (December 2008), "Fear of 'Other's: Social Exclusion and the European Crisis of Solidarity", Social Policy and Administration, Vol. 42, No. 6, pp.676-690.

Elections to the German Bundestag, Retrieved at: March 18, 2012, http://www.electionresources.org/de/

Ellinas, A. A., (2010), The Media and the Far Right in Western Europe: Playing the Nationalist Card, Cambridge University Press, Cambridge.

European Movement International (2014), "European Elections 2014: A First Look ProEuropean Perspective", Retrieved at: September 27, 2014 http://europeanmovement.eu/wp-content/uploads/2014/06/EP2014-Analysis.pdf

Federal Elections in Austria, Retrieved at March 8, 2012, http://www.electionresources.org/at/

Fekete, L., (2012), "Pedlars of Hate: The Violent Impact of the European Far Right", Institute of Race Relations, London, pp. 1-44.

Fligstein, N. et al., (2012), "European Integration, Nationalism and European Identity", Journal of Common Market Studies Vol. 50, (S1), pp. 106-122.

Gingrich, A., (1998), Frontier Myths of Orientalism: The Muslim World in Public and Popular Cultures of Central Europe. In: B. Bojan and B. Borut (eds.) MediterraneanEthnological Summer School 2, Institute for Multicultural Studies, Ljubljana, pp. 99-127.

Goodwin et al., (February 2012), "The New Radical Right: Violent and Non-Violent Movements in Europe", Institute for Strategic Dialogue, Briefing Paper, London, pp.157.

Gowland, D. et al., (2006), The European Mosaic, Prentice Hall, London.

Guibernau, M., (March 2010), "Migration and the Rise of the Radical Right", Policy Network Paper, London, pp. 1-19.

Günay, C., (2009), Avusturya. In: S. Akşit et al (eds.), Avrupa Birliği Ülkelerinden Türkiye'nin Üyeliğine Bakış, Zeplin İletişim, Ankara, pp. 97-112.

Hainsworth, P., (2008), The Extreme Right in Western Europe, Routledge, New York.

Hainsworth, P., (2000), Introduction: The Extreme Right. In: P. Hainsworth (ed.), The Politics of the Extreme Right: From The Margins to the Mainstream, Pinter Pub., London.

Hamilton, F., (2009, September 3), "British National Party Forced to Admit Non-whites", The Times. 
Howard, M. M., (2001), “Can Populism be Suppressed in a Democracy?”, East European Politics and Societies, Vol.14, No.2, pp.18-32.

Interview with a Federal Parliamentarian from FPÖ, (May 15, 2012), conducted by the author in Vienna.

Langenbacher, N. \& B. Schellenberg, (2011), Introduction: An Anthology about the Manifestations and Development of the Radical Right in Europe. In: N. Langenbacher \& B. Schellenberg (eds.), Is Europe on the "Right" Path?: Right-wing Extremism and Right-wing Populism in Europe, Friedrich Ebert Stiftung, Forum Berlin, pp.11-25.

Ludvig, A., (September 2004), "Why Should Austria be Different from Germany? The Two Recent Nationality Reforms in Contrast", German Politics, Vol.13, No.3, pp. 499-515.

Minkenberg, M., (2011), "The Radical Right in Europe Today: Trends and Patterns in East and West". In: N. Langenbacher \& B. Schellenberg (eds.), Is Europe on the 'Right' Path?: Right-wing Extremism and Right-wing Populism in Europe,Friedrich Ebert Stiftung, Forum Berlin, pp.37-56.

Mudde, C., (2014), “The Far-Right and the European Elections”, Retrieved at October 19 2014: http://www.unitedagainstracism.org/wp-content/uploads/2014/05/Cas-

Mudde-Euro-elections-2014_CH-article.pdf

Mudde, C., (2013), “The 2012 Stein Rokkan Lecture: Three Decades of Populist Radical Right Parties in Western Europe: So What?", European Journal of Political Research, Vol. 52, pp.1-19.

Mudde, C., (May 2012), "The Relationship between Immigration and Nativism in Europe and North America”, Migration Policy Institute, Washington, pp.1-32.

Mudde, C., (2007), Populist Radical Right Parties, Cambridge University Press, Cambridge.

Mudde, C., (1999), "The Single-issue Party Thesis: Extreme Right Parties and the Immigration Issue”, West European Politics, Vol. 22, No.3, pp. 182-197.

Nedelcu, H. \& C. Miller, (2011), "Migration and the Extreme Right in Western Europe", Review of European and Russian Affairs, Vol.6, No.1, pp. 55-64.

Norris, P., (2005), Radical Right: Voters and Parties in the Electoral Market, Cambridge University Press, Cambridge.

Party Programme of the Freedom Party of Austria (FPÖ), (2011), www.fpoe.at, Retrieved at February 12, 2012.

Party Programme of National Democratic Party of Germany (NPD), (2010), Retrieved at February 16, 2012,_http://www.npd-sh.de/index.php

Party Programme of NPD for Europe, (2003), Retrieved at May 18, 2012, http://www.partyprogrammeofnpdforeurope.pdf

Poggioli, S., (2006), “Anti-immigrant Policy Boosts France's Le Pen Again”, NPR-Morning $\begin{array}{llll}\text { Edition, } & \text { Retrieved } & \text { at } & \text { 2012, }\end{array}$ www.npr.org/templates/story/story.php?storyId $=6522463$

Schellenberg, B., (2011), The Radical Right in Germany: Its Prohibition and Reinvention. In: N. Langenbacher \& B. Schellenberg (eds.) Is Europe on the "Right" Path?: Right- 
wing Extremism and Right-wing Populism in Europe, Friedrich Ebert Stiftung, Forum Berlin, pp. 57-82.

Schmied, M. \& W. Wieshaider, (2004), Islam and the European Union: The Austrian Way. In: R. Potz \& W. Wieshaider (eds.), Islam and the European Union, Peeters, Leuven, pp.199-217.

Schori Liang, C., (2007), Europe for the Europeans: The Foreign and Security Policy of the Populist Radical Right. In: C. Schori Liang (ed.), Europe for the Europeans: The Foreign and Security Policy of the Populist Radical Right, Ashgate, London, pp.1-32.

Schulz, M., (2011), Combating Right-wing Extremism as a Task for European Policy Making. In N. Langenbacher and B. Schellenberg (eds.), Is Europe on the "Right" Path?: Right-wing Extremism and Right-wing Populism in Europe, Friedrich Ebert Stiftung,Forum Berlin, pp. 27-36.

Strasser, S., (2008), "Europe's Other: Nationalism,Ttransnationals and Contested Images of Turkey in Austria”, European Societies Vol.10, No.2, pp.177-195.

Vasilopoulou, S., (2011), "European Integration and the Radical Right: Three Patterns of Opposition”, Government and Opposition, Vol.46, No.2, pp. 223-244.

Williams, M. H., (2010), "Can Leopards Change Their Spots? Between Xenophobia and Trans-ethnic Populism among West European Far Right Parties”, Nationalism and Ethnic Politics, Vol. 16, pp. 111-134.

Williams, M. H., (2006), The Impact of Radical Right-Wing Parties in West European Democracies,Palgrave Macmillan, New York.

Wilson, R. \& P. Hainsworth, (2012), "Far-right Parties and Discourse in Europe: A Challenge for Our Times", Report of European Network Against Racism, Brussels, pp.1-28.

Zuquete, J. P., (October 2008), “The European Extreme-right and Islam: New Directions?”, Journal of Political Ideologies Vol.13, No.3, pp. 321-344. 